\title{
PAG electrophoregrams of wheat cultivars grown in Finland
}

\author{
TUULA SONTAG and HANNU SALOVAARA \\ Department of Food Chemistry and Technology, University of Helsinki, \\ SF-00710 HELSINKI, Finland
}

\begin{abstract}
The polyacrylamide gel electrophoretic (PAGE) patterns of gliadins of 9 spring wheat cultivars (Apu, Drabant, Taava, Tapio, Ulla, Kadett, Luja, Ruso and Tähti) and of 5 winter wheat cultivars (Aura, Ilves, Linna, Nisu and Vakka) were determined. Most of the samples studied had specific gliadin PAGE patterns, indicating that electrophoregrams obtained with the procedure employed here can be used for identifying wheat cultivars grown in Finland. Only two cultivars, Taava and Ruso, which are close relatives, possessed similar PAGE patterns. The procedure uses a commercial vertical electrophoresis apparatus and thin gels. Up to 28 samples could be electrophoresed in three hours and analyzed after staining. The procedure can be applied in the identification of wheat cultivars currently grown in Finland.
\end{abstract}

Index words: Wheat, gliadins, electrophoresis, cultivar identification.

\section{Introduction}

Polyacrylamide gel electrophoresis (PAGE) is extensively applied to wheat cultivar identification in breeding programs and other connections where accurate information on the identification of a small wheat sample is needed. The procedure separates the alcohol soluble proteins, or gliadins, of wheat endosperm into protein bands of different electrophoretic mobilities and intensities. Cultivars have band patterns (electrophoregrams) that are characteristic of the genotype and independent of growth conditions (WRIGLEY 1970,
Zillman and BushuK 1979). BushuK and ZilLMAN (1978) developed a gliadin PAGE method for wheat which has also been recommended as a reference method for wheat cultivar identification by the International Association for Cereal Science and Technology (ICC) (ANON. 1984).

The interest of institutes and industry towards the identification of wheat cultivars by electrophoresis has increased in Finland. Therefore the need for reference data on wheat electrophoregrams of the cultivars grown in Finland has become evident. It was the aim of the present study to produce ref- 
Table 1. Data of the spring and winter wheat cultivars grown in Finland and examined in the present study.

\begin{tabular}{lllc}
\hline Name of cultivar & Breeder & Origin & $\begin{array}{c}\text { Put on } \\
\text { the market }\end{array}$ \\
\hline Spring wheats & & & 1949 \\
Apu & Jo $^{1}$ & Garnet/Pika & 1972 \\
Drabant & WW $^{2}$ & cI 12633/Ring & 1978 \\
Hankkija's Taava & $\mathrm{Hja}^{3}$ & ${ }^{0}$ Co mutant from Ruso & 1979 \\
Hankkija's Tapio & $\mathrm{Hja}$ & Hja c3929/Kolibri & 1975 \\
Hankkija's Ulla & $\mathrm{Hja}$ & Tammi/Hja a4431 & 1981 \\
Kadett & WW & Kolibri/Pompe & 1981 \\
Luja & Jo & Svenno//Hopea/Tammi & 1967 \\
Ruso & $\mathrm{Hja}$ & Reward/Pika//free poll. & 1972 \\
Tăhti & Jo & Kärn//Aurora/Pika & 1975 \\
Winter wheats & & & 1984 \\
Aura & Jo & Ertus/Vakka & 1965 \\
Hankkija's Ilves & $\mathrm{Hja}$ & Hja b356/Vakka & 1966 \\
Linna & Hja & Panu/Hja 04819//Virtus & 1953 \\
Nisu & Jo & Varma/Kehra & \\
Vakka & Jo & Varma/Kehra & \\
\hline
\end{tabular}

1 = Agricultural Research Centre, Department of Plant Breeding, SF-31600 Jokioinen

$2=$ W.Weibul AB, Sweden

3 = Hankkija Plant Breeding Institute, SF-04300 Hyrylä

erence data on the PAG electrophoregrams of spring and winter wheat cultivars currently grown in Finland.

\section{Materials and methods}

\section{Samples}

Samples of 14 wheat cultivars were obtained from the cultivar collection maintained by the Finnish State Seed Testing Station. Complete name, breeder, pedigree and the year the cultivar had been released on the market are shown in Table 1. As a reference sample served Canadian cultivar Marquis, which was received from Dr. W. Bushuk (University of Manitoba, Canada).

\section{Reagents}

Acrylamide (for electrophoresis, $2 \times$ crystallized) and Serva blau R-250 (C.I. 42660) were obtained from Serva Feinbiochemica; aluminium lactate was obtained from Fluka; N,N'-methylene-bisacrylamide from BDH Chemicals Ltd; ammoniumperoxodisulphate, $\mathrm{L}(+)$-ascorbic acid, ferrosulphate $\left(\mathrm{FeSO}_{4} \times 7 \mathrm{H}_{2} \mathrm{O}\right)$, methyl green and trichloroacetic acid were obtained from E.Merck; lactic acid was obtained from the Pharmacy of University of Helsinki. All the reagents were analytical grade.

\section{Apparatus}

The electrophoresis apparatus was a Pharmacia Gel Electrophoresis Apparatus GE-2/4 LS (Sweden) with a LKB 2103 Power Supply (Sweden).

\section{Preparation of the gels}

The gel solution was prepared by the recipe of Maier and Wagner (1980) (Table 2). The gels $(140 \times 180 \times 1.5 \mathrm{~mm})$ were polymerized as described previously (Sontag et al. 1985). Before use they were kept overnight at $4^{\circ} \mathrm{C}$. The gels were usable $1-2$ weeks after preparation. 
Table 2. Recipes for gel and tank buffer solutions.

\begin{tabular}{lc}
\hline Solution & Amount required \\
\hline Gel, $1000 \mathrm{ml}$ & \\
Acrylamide, $\mathrm{g}$ & 60.0 \\
$\mathrm{~N}, \mathrm{~N}^{\prime}-$ Methylene bisacrylamide, $\mathrm{g}$ & 3.0 \\
Ascorbic acid, g & 1.0 \\
FeSO $\mathrm{H}_{4} \times 7 \mathrm{H}_{2} \mathrm{O}, \mathrm{g}$ & 0.046 \\
Aluminium lactate, g & 2.5 \\
Lactic acid, ml & to $\mathrm{pH} 3.2$ \\
Catalyst, $100 \mathrm{ml}$ & \\
Ammonium persulphate, g & 1.4 \\
Tank buffer, $1000 \mathrm{ml}$ & \\
Aluminium lactate, g & 2.5 \\
Lactic acid, ml & to $\mathrm{pH} 3.2$ \\
\hline
\end{tabular}

\section{Sample preparation}

Whole wheat kernels were ground by hand using a mortar and pestle. The ground grain was extracted with three times its weight of $70 \%$ aqueous ethanol in a stoppered centrifuge tube. The tube was allowed to stand at room temperature for $1 \mathrm{~h}$ with occasional mixing on a vortex mixer and then centrifuged for $10 \mathrm{~min}$ at $3500 \times \mathrm{rpm}$. The supernatant was removed to a vial $(1.5 \mathrm{ml})$ and diluted with two times its volume of sample buffer. The buffer was made of tank buffer with $30 \%$ saccharose to increase the density of the protein solution and $1 \%$ methyl green to serve as a marker dye and to show how the sample layered in the gel slot. Gliadin extracts were stored at $4^{\circ} \mathrm{C}$ in sealed vials until use. Freezing of the gliadin extracts seemed to cause great losses in band intensities of the anodic bands.

\section{Electrophoresis}

The gliadin extracts $(10 \mu \mathrm{l})$ were loaded into the 14 gel slots with microliter syringe. The gliadin extract of the cultivar Marquis was placed in each gel to serve as a reference sample.

Electrophoresis was performed at $400 \mathrm{~V}$ for about $3 \mathrm{~h}$ and buffer temperature was maintained at $16^{\circ} \mathrm{C}$ by tapwater circulation. Electrophoresis was allowed to proceed until the second (purple) marker dye band of methyl green had migrated to exactly $0.5 \mathrm{~cm}$ form the end of the gel. During this time the albumins and globulins that the protein extract also contains run off the gel leaving only the gliadins on the gel (KHAN 1982).

\section{Staining and photography}

The gel was stained overnight $(16 \mathrm{~h})$ in a solution of $5 \mathrm{ml}$ of an $94 \%$ ethanol solution of $1 \%$ Serva blau R-250 diluted with $200 \mathrm{ml}$ of $12 \%$ trichloroacetic acid. After staining the gel was rinsed with water and photographed. The stained gel was placed on a glass plate on a light box and illuminated from below and photographed with Agfaortho 25 film.

\section{Determination of mobilities and intensities}

The relative mobilities $(\mathrm{Rm})$ and relative intensities (Ri) of gliadin bands were evaluated by the procedure of BUSHUK and ZiLlmaN (1978). Rm values were determined by measuring the migration distance of the gliadin band from the origin (point of sample application) to the centre of the band. The migration distance of the given band divided by the migration distance of a specific band, termed band 50 (Fig. 1), of the cultivar Marquis on the same gel and the result multiplied by 50 gave the band intensities were rated subjectively by visual examination of the band staining intensities by a number from 1 to 5 , with 5 representing the most intensely stained and 1 the most weakly stained bands.

\section{Reproducibility}

Duplicate electrophoresis of each of the four replicate samples was performed to ensure visual similarity of the electrophoresis formula of replicates. Reproducibility of the electrophoretic procedure used in this study was determined by measuring the relative mobilities of three bands in the electrophoregram of the standard cultivar Marquis (Fig. 1) on 


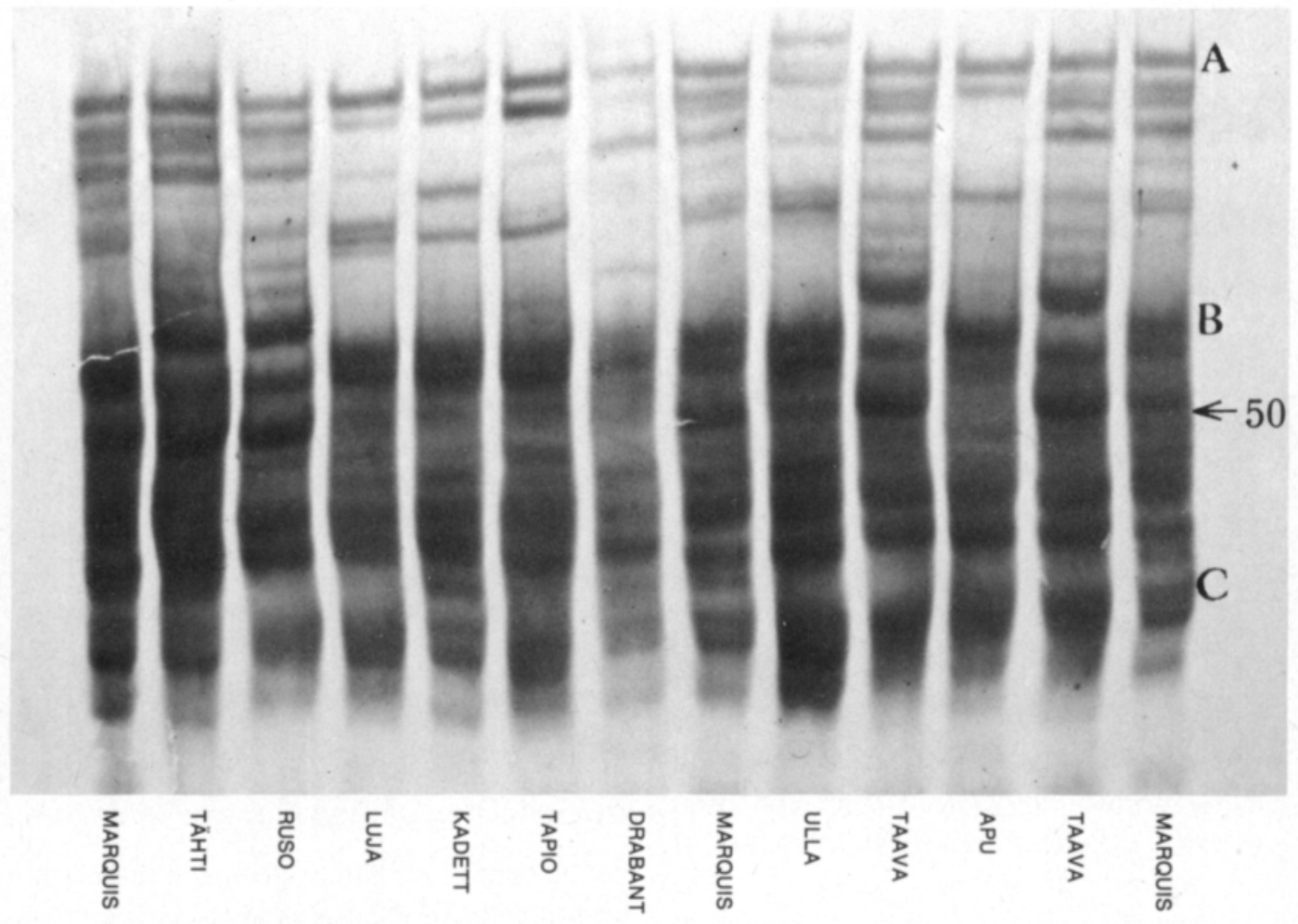

Fig. 1. Electrophoregrams of gliadins from 9 spring wheat cultivars grown in Finland and reference cultivar Marquis. From left to right: Marquis, Tảhti, Ruso, Luja, Kadett, Tapio, Drabant, Marquis, Ulla, Taava, Apu, Taava, Marquis.

8 different gels. The coefficients of variation for the relative band mobilities of band $\mathrm{A}$ $(R m=17)$, band $B(R m=45)$ and band $C$ $(\mathrm{Rm}=68)$ were $2.9 \%, 1.2 \%$ and $4.0 \%$, respectively.

\section{Results}

Electrophoregrams of the wheat cultivars analyzed in this study are shown in Fig. 1 and 2. Electrophoregram formulas for these wheat cultivars expressed by relative band mobility and band intensity are given in Table 3 .

All the cultivars studied could be identified by their electrophoregrams. The most distinct differences between the gliadin patterns of these cultivars are found in the anodic part of their electrophoregrams.

The spring wheat cultivars studied could be divided into three groups on the base of the pattern of their anodic bands. Three of the cultivars, i.e. Tähti, Ruso and Taava were distinguished by an anodic band pattern characteristic also of the Canadian cultivar Marquis which was used as a reference. However, in spite of this similarity there was a distinct difference in the cathodic region of the bands between cultivars Tähti, Ruso and Marquis, making identification possible (Fig. 1). Taava had exactly the same gliadin pattern as Ruso. These two cultivars are close relatives, Taava being ${ }^{60} \mathrm{Co}$-mutant of Ruso, which explains the similarity of their gliadin patterns.

Five cultivars, i.e. Apu, Drabant, Tapio, Kadett and Luja, had fewer anodic bands than Ruso, Taava and Tähti (Fig. 1). Distinct differences were seen between the anodic band patterns of these five cultivars permitting precise identification. One of the spring wheat cultivars, i.e. Ulla, had a strong anodic band 
Table 3. Electrophoretic formulas of gliadins of 14 wheat cultivars grown in Finland.

Mobility of bands relative to Marquis standard band and relative intensities of bands (scale 1 to 5)

Spring wheats

Marquis 17(4), 20(3), 22(3), 25(3), 28(1), 31(2), 34(2), $45(5), 46(5), 50(5), 53(2), 55(3), 57(2), 59(3)$, 63(4), 65(3), 68(3), 71(4), 80(2), 82(3)

Apu 17(4), 20(3), 31(3), 40(1), 45(5), 47(4), 50(2), $53(3), 55(2), 59(4), 63(4), 65(1), 68(3), 71(3)$, $80(2)$

Drabant 15(2), 17(4), 21(2), 25(4), 38(2), 45(5), 46(5), 49(3), 50(3), 53(2), 56(3), 59(4), 63(4), 65(3), 68(3), 71(4), 80(2), 82(1)

Kadett 15(2), 17(4), 21(2), 25(1), 28(2), 35(3), 45(5), 46(5), 49(3), 50(3), 53(2), 56(4), 59(4), 63(4), 65(3), 68(3), 71(4), 80(2), 82(1)

Luja 17(4), 20(3), 26(1), 30(3), 34(3), 35(2), 45(5), $46(5), 48(4), 50(3), 53(3), 55(3), 57(3), 59(4)$, 63(4), 68(2), 71(4), 80(2)

Ruso 17(4), 20(3), 22(3), 25(4), 28(1), 31(2), 36(2), $38(2), 40(5), 46(5), 48(3), 50(5), 53(3), 55(3)$, 57(3), 59(3), 63(4), 65(1), 68(3), 71(4), 80(3)

Taava 17(4), 20(3), 22(3), 25(4), 28(1), 31(2), 36(2), $38(2), 40(5), 46(5), 48(3), 50(5), 53(3), 55(3)$, 57(3), 59(3), 63(4), 65(1), 68(3), 71(4), 80(3)

Tapio 17(4), 19(4), 23(1), 26(1), 30(2), 34(3), 40(1), 45(5), 48(4), 53(3), 55(3), 55(3), 57(3), 59(4), 62(4), 65(2), 71(4), 80(2)

Tähti 15(1), 17(4), 20(3), 22(3), 25(4), 28(1), 31(2), 36(2), 38(2), 40(5), 46(5), 48(3), 50(5), 53(3), 55(3), 57(3), 59(3), 63(4), 65(4), 67(3), 68(3), 71(4), 80(3), 85(3)

Ulla 14(3), 17(3), 19(3), 23(2), 24(1), 26(2), 30(3), $34(3), 35(2), 45(5), 46(5), 50(3), 53(2), 55(3)$, $57(3), 59(3), 63(3), 65(2), 68(3), 71(4), 80(3)$, $82(1)$

Winter wheats

Aura 15(2), 17(4), 21(2), 28(1), 30(1), 32(2), 40(2), $45(5), 46(5), 49(3), 50(3), 53(2), 55(4), 57(4)$, $59(3), 62(4), 65(3), 69(2), 71(3), 77(2)$

Ilves 17(5), 20(3), 22(3), 25(4), 28(2), 30(2), 31(1), $34(3), 45(5), 46(5), 49(3), 50(5), 53(3), 55(4)$, 59(4), 60(4), 62(4), 65(3), 69(2), 71(4), 77(4), $80(2), 82(2)$

Linna 15(2), 17(5), 21(2), 30(1), 31(3), 35(1), 40(2), 45(5), 46(5), 49(3), 50(2), 53(5), 55(4), 57(3), $60(4), 62(4), 65(2), 69(3), 71(4), 74(3), 77(3)$, $80(2), 82(2)$

Nisu 15(4), 17(4), 21(2), 25(3), 28(1), 30(2), 35(1), $38(3), 45(5), 46(5), 49(3), 53(5), 55(3), 57(3)$, 60(4), 62(4), 65(3), 69(2), 71(4), 77(3), 80(2)

Vakka 15(2), 17(4), 21(2), 30(2), 31(2), 34(3), 45(5), 46(5), 49(3), 53(5), 55(4), 57(4), 60(4), 62(4), 65(3), 69(3), 71(4), 77(3) pattern which could not be detected in any other spring wheat cultivar studied.

The winter wheat cultivars also had characteristic band patterns by which they were identifiable. The four cultivars Vakka, Nisu, Linna and Aura shared three anodic bands in similar positions (Fig. 2). However, differences in the rest of the anodic bands facilitated identification. The fifth winter wheat cultivar studied, Ilves, showed an anodic pattern with distinct differences as compared to the rest of the winter wheat cultivars. A considerable part of the electrophoregram obtained from Ilves had close similarity with spring wheat cultivars Ruso and Tähti (Fig. 1 and 2). However, Ilves was clearly characterized by the location of its bands in the central part of the electrophoregram.

\section{Discussion}

Analysis of the gliadin electrophoregrams serves as a useful tool for research especially in wheat breeding, where accurate identification of breeding lines is needed. The electrophoretic method has several serious shortcomings in other applications where rapid cultivar identification of commercial parcels is desirable. The small sample size may be an advantage in plant breeding work but it is subject to many problems when cargoes of wheat should be characterized for their cultivar composition. However, the electrophoretic procedure described here has found recent application in the wheat processing industry for the verification of certain lots of wheat of suspected variety. The procedure used in this study is a modification of the reference method deviced by the International Association for Cereal Science and Technology (ANON. 1984). In the present study a commercially available apparatus was used. Further deviations in the method were a smaller gel size and the use of a greater number of samples on one gel.

It should be realized that the ICC standard procedure is primarily not developed for routine work but rather to serve as a general ref- 


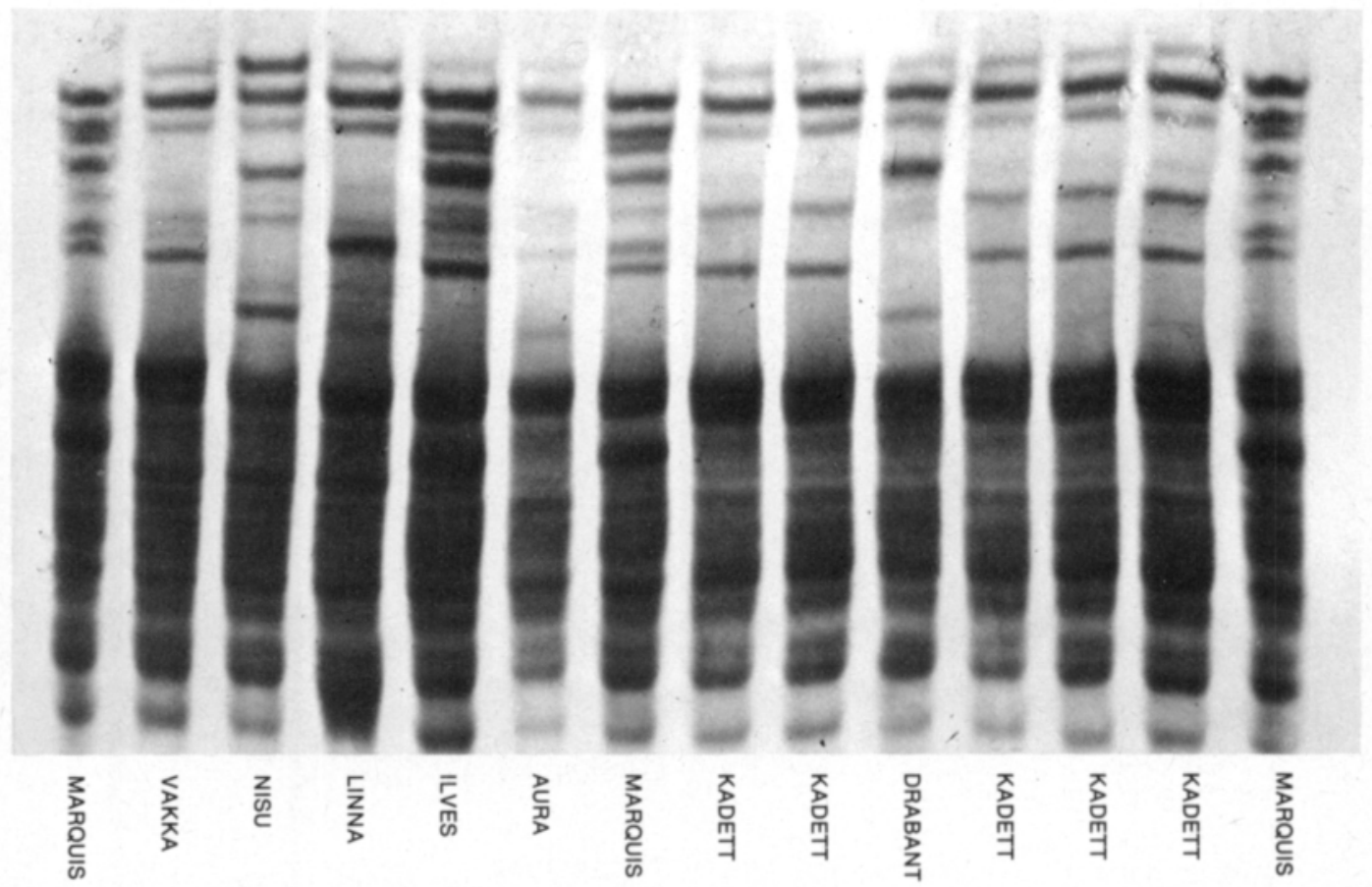

Fig. 2. Electrophoregrams of gliadins from 5 winter wheat cultivars grown in Finland and reference cultivar Marquis. From left to right: Marquis, Vakka, Nisu, Linna, Ilves, Aura and Marquis.

erence method applicable in situations where a comparability of data is needed. Like the functional quality of wheat protein, the gliadin electrophoretic pattern is cultivar specific. Although a part of the functional quality of wheat proteins is associated with gliadins, evidence for a systematic relationship has not been found between the breadmaking quality of wheat cultivars and the electrophoretic pattern of gliadins. Instead, a relationship may exist between the band patterns obtained from the glutenin fraction of the cultivars in a sodium dodecylsulphate polyacrylamide gel electrophoresis (SDS-PAGE) and the breadmaking quality of wheat cultivars (PAYNE et al. 1979, 1981 and MoONEn et al. 1982, 1984). Our subsequent work will be concentrated on possible relationships between SDS-PAGE band patterns and the functional properties of wheat cultivars grown in Finland.

Acknowledgements. The authors are grateful to $\mathrm{Mr}$ Osmo Ulvinen in the Finnish Seed Testing Station for the wheat cultivar samples. The work was financed in part by the Grain Research Committee, Finland and the Finnish cultural Foundation.

\section{References}

Anon. 1984. ICC Draft Standard No. 143. Wheat cultivar identification by polyacrylamide gel electrophoresis of the gliadin proteins.

BushuK, W. \& Zillman, R.R. 1978. Wheat cultivar identification by gliadin electrophoregrams. I. Apparatus, method and nomenclature. Can. J. Plant Sci. 58: 505-515.

Кнал, 1982. Polyacrylamide gel electrophoresis of wheat gluten proteins. Bakers Dig. 56, 5: 14-19.

Moonen, J.H.E., Scheepstra, A. \& Graveland, A. 1982. Use of the SDS-sedimentation test and SDS polyacrylamide gel electrophoresis for screening breeder's samples of wheat for bread-making quality. Euphytica 31: $677-690$.

-, Scheepstra, A. \& Graveland, A. 1984. Genetische Aspecte des Glutenins im Zusammenhang mit der Back- 
făhigkeit deutscher Weizensorten. Die Muhle u. Mischfuttertechnik. 10: 124-126.

Payne, P. J., Corfield, K.G. \& Blackman, J.A. 1979. Identification of a high-molecular-weight subunit of glutenin whose presence correlates with bread-making quality in wheats of related pedigree. Theor. Appl. Genet. 55: 153-159.

-, Corfield, K.G., Holt, L.M. \& Blackman, J.A. 1981. Correlations between the inheritance of certain high-molecular-weight subunits of glutenin and breadmaking quality in progenies of six crosses of bread wheat. J. Sci. Food Agric. 32: 51-60.

Sontag, T., Salovaara, H. \& Ulvinen, O. 1985. PAG electrophoregrams of six Finnish potato cultivars. J. Agric. Sci. Finl. 57: 147-153.

WRIGLEY, C.W. 1970. Protein mapping by combined gel electrofocusing and electrophoresis: Application to the study of genotypic variations in wheat gliadins. Biochem. Genet. 4: 509-516.

Zillman, R.R. \& BushuK, W. 1979. Wheat cultivar identification by gliadin electrophoregrams II. Effects of environmental and experimental factors on the gliadin electrophoregram. Can. J. Plant Sci. 59: 281-286.

Ms received October 4, 1985

\title{
SELOSTUS
}

\section{Suomessa viljeltyjen vehnälajikkeiden PAG-elektroforegrammit}

\author{
Tuula Sontag ja Hannu Salovaara \\ Helsingin yliopiston elintarvikekemian ja \\ -teknologian laitos, \\ $00710 \mathrm{Helsinki}$
}

Polyakryyliamidigeelielektroforeesilla (PAGE) määritettiin vehnăn gliadiinien elektroforegrammit 14 Suomessa viljeltăvăstă vehnălajikkeesta. Tutkimuksessa oli 9 kevătvehnălajiketta (Apu, Drabant, Hankkijan Taava, Hankkijan Tapio, Hankkijan Ulla, Kadett, Luja ja Ruso) ja 5 syysvehnälajiketta (Aura, Hankkijan Ilves, Linna, Nisu ja Vakka). Kaikilla tutkituilla lajikkeilla oli tyypillinen gliadiinien elektroforegrammi, lukuunottamatta kahta pe- rimältaaăn lähekkäistä lajiketta, Taavaa ja Rusoa, joilla oli samanlaiset gliadiinien elektroforegrammit. Tutkimuksessa kăytetyllă vertikaalisella elektroforeesilaitteella kyettiin yhdellă ajokerralla măărittămaaăn 28 gliadiininäytettă. Elektroforeesiajo kesti kolme tuntia ja vărjảys 12 tuntia. Menetelmäă voi kảyttảă suomalaisten vehnălajikkeiden aitoustutkimuksessa. 